\title{
Possessive attachments: Identity beliefs, equality law and the politics of state play Davina Cooper
}

\begin{abstract}
One feature of the neo/ liberal possessive self is the propertied character of certain beliefs: treated as belonging to those who hold them, recognised and supported in acting on the world, and protected. While an ownership paradigm predates anti-discrimination and human rights regimes, these regimes have consolidated and extended the propertied status of certain identity beliefs in ways that naturalise and siloise them. But if beliefs' propertied character is politically problematic, can it be unsettled and reformed? This paper considers one possible mode for doing so, namely play. Oftentimes, play works to secure and assert the propertied attachments people have to their beliefs; but some forms of play offer other possibilities. Focusing on the state as a complex site of play relations and encounters, this article explores how state play engages identity beliefs in a contemporary legal drama of colliding beliefs between conservative Christians and liberal gay equality advocates.
\end{abstract}

This article contributes to the question of how neo/ liberal states in the global north play and what such play might do. Conventionally associated with instrumental, coercive action and dominance, states in the north are assumed to demonstrate logics and affects that are far from playful. At the same time, a growing body of work has explored these and other states' relationship to play, from the use of satire in anti-government protests and game-playing between states and politicians, to institutional theatrics, and the gamification of resource allocation decisions (eg Edwards, 2013; Lerner, 2014; Rai 2015; Shepard 2011). ${ }^{1}$ For the most part, however, scholarship in this area treats the neo/ liberal state as either play's subject or its object. This article takes a different approach, tracing the complex interrelationship of states to play in conditions where state bodies design and mobilise play while simultaneously functioning as the terrain, target and resources of play by others. Through such play, states and citizens constitute their division from one another, but play also provides a register for acts of fusion, contact, and corporeal exchange.

Exploring these interconnected processes, this article focuses on state-based play in relation to the "propertisation" of beliefs. Specifically, it explores how play "plays with" the possessive ties attaching beliefs to their holders. Treating beliefs as belonging in propertylike ways is not a modern development; however, this discussion focuses on contemporary anti-discrimination and human rights law's contribution to propertising authorised beliefs about one's own and others' identities. While may deem these laws an important progressive 
development, one effect they have had has been to entrench certain identities and beliefs as things that "belong". The problems this causes are highlighted when legally recognised identities and beliefs collide, for instance when people's legally accepted attachment to a gay identity (and to beliefs about the equality of this identity) clash with others' legally recognised (if less accepted) beliefs that gay sexuality is sinful and deviant.

The litigation and wider legal drama to surface as a result of colliding conservative Christian and liberal gay beliefs about sexuality is the subject of this article. Arising most prominently in Britain, Canada, and the US and, to a lesser extent, in Australia and New Zealand, this conflict constitutes the latest stage in conservative Christianity's far longer struggle over gender and sexuality. Having opposed decriminalisation, and the extension of human rights and anti-discrimination laws to gay people with limited success, conservative Christians in the late 1990s were compelled to change strategy. ${ }^{2}$ Their new approach focused less on challenging the legitimacy of gay rights and equality than on defending religious people's right to "conscientiously object". Cases to end up in court included Christian registrars, florists, photographers, cake-makers and venue owners claiming a legal entitlement to deny services and accommodation to same-sex couples on grounds of religious belief. Other cases involved school districts refusing to make gay-positive books available to teachers or students; and universities, student bodies and youth organisations denying "out" gays membership (Cooper and Herman, 2013; Malik, 2011; Pynes 2016; Stychin, 2009). The withdrawal, however, of rights, resources and recognition was not just on one side. An important effect of conservative Christian refusal was the corresponding withdrawal of promotions, partnerships, recognition, subsidies and accreditation by public (and other) bodies. In one British case, a religious couple who wanted to foster but could not promise to present gay sexuality as a valid choice to youngsters in their care found themselves confronting a local authority that refused to advance their application. ${ }^{3}$ In another case, a Canadian Christian college's prohibition of same-sex relationships for students and staff precipitated a decision by provincial legal bodies not to recognise their new law degree. ${ }^{4}$

This article takes up the legal drama over conservative Christian withdrawal to think about play; specifically, how and whether play can unsettle possessive beliefs. Exploring play through a legal drama of conservative Christian withdrawal may seem counter-intuitive given how seriously participants treated the stakes. But aside from the fact that gravity does not negate play's presence, play proved a frame that participants - both explicitly and implicitly drew upon. Certainly, at times, play seemed to consolidate and entrench possessive beliefs; 
however, this article centres upon those instances where state-based play - from role-play and experimentation, to a political kind of clambering and ideological mischief - seemed to do something else. It is tempting to romanticise such play, to suggest it can unsettle propertied attachments; and certainly the forms of play I discuss did invoke some transfer of beliefs between bodies (individual, collective and institutional), or at least its simulation. However, the primary aim of this discussion is not to determine conclusively what play can do, but to explore the diverse ways play frames and shapes political relations, recognising that, in the process, larger questions emerge: namely, whether state-based politics in the neo/ liberal north would benefit from more play; what kinds of play this might be; and the conditions required for people to play "well" with states?"

\section{Possessive Beliefs and Play}

In his influential account of "possessive individualism", CB Macpherson (1962) addressed the foundational place of property relations within liberal political theory, including in its understanding of the subject (coded as white, European and male) as owner of both his person and capacities. ${ }^{6}$ Approaching beliefs, today, as things that can also be "held" and possessed similarly reveals the extending power of property discourse, as religious, ontological and moral beliefs get constituted as the legally recognised social property of individual and group subjects within the neo/ liberal north (Cooper and Herman, 2013). The concept of beliefs as property does not mean beliefs are market-alienable, any more than other social properties such as whiteness (Harris, 1993; Grabham, 2009; Keenan, 2010). Rather, what it suggests is that "core" identity beliefs, including the belief that gay sexuality is natural and normal, as well as the countervailing belief that gay sexuality is sinful, deviant and outside of God's plan, have become legally recognised as belonging to subjects in some deeply intimate way, authorising holders' control over what the beliefs are; how they might be shared; and establishing their right to protection from invasion, defacement or destruction (also Nedelsky, 1990). Like Margaret Radin's (1993) “property for personhood”, human rights and anti-discrimination discourse treats sex, gender and religious identity beliefs as property because they are deemed integral to enriched forms of personhood. In other words, if paradoxically, law treat identity beliefs (that is, beliefs closely attached to particular identities) as worthy of property-like protection and recognition largely because they are deemed not to actually resemble property - at least as commodified and severable things. 
In recent years, British courts have engaged in extensive property thinking in relation to anti-gay religious refusal as they address the parameters of protectable manifested beliefs: ${ }^{7}$ What counts as a core aspect of the religion such that exemption from anti-discrimination law (or, alternatively, recognition of the claimant's right to anti-discrimination protection) might be permitted $?^{8}$ Do the courts have the right to make such theological determinations or is the scope of the propertied object, namely what elements comprise a particular faith, subject only to the judgment of its religious "holders"? 9 And how far should property-like protections extend; do they extend to "social" remarks about homosexuality - those expressed on an employee's personal Facebook page, for instance, or by email to colleagues from an office computer after work, or to co-workers in an office $?^{10}$ While British courts have limited the reach and force of religious beliefs about sexuality in terms of what they can accomplish, court judgments nevertheless confirm the normalised status of property thinking in understanding religious beliefs. But if beliefs are treated as property, what, if anything, is wrong with this?

Discussing dispossession, Judith Butler and Athena Athanasiou (2013) explore the relationship between two of its meanings: dispossession as loss of land and livelihood; and the recognition that we are not atomistic, self-owning individuals. Arguments against possessive beliefs resonate with this latter claim. While the tie-up between possessive beliefs and individualism is complicated by the fact courts and participants also recognise identity beliefs as collectively held - with individuals described as belonging to their beliefs as much as the reverse - a primary rationale for protecting beliefs lies in individual freedom and growth. Like other dimensions of the liberal possessive self, affirming property in identity beliefs narrates a nomos of stable unitary subjects - each set apart from others, holding tight to their own beliefs, beliefs that belong to them, on which they are free to act, and on which, when they collide with other beliefs or identity statuses, the courts will adjudicate. As such, identity beliefs are treated like one's children, partner or home, a constitutive part of intimate life, upon which others should not trespass, and about which they should not cast aspersions. But identity beliefs - outside their framing in liberal legal discourse - are not that private or reified. Socialised and relational in their conditions of emergence, evolution and change, identity beliefs circulate promiscuously, evolving, touching and being "held" (in the sense of being known and invoked) by diverse actors including those with no affinity or commitment to the beliefs in question. Many beliefs, including those that end up in court in litigation over conservative Christian withdrawal, are fundamentally political - addressing other people's 
ways of living and, as such, deeply contested. Treating beliefs as personal property depoliticises the values and social relations underpinning and fortified by them. While it protects and empowers particular beliefs - ostensibly out of respect for the frameworks of which they are part, and for the subjects who hold them - treating knowledge claims about the world as intimate property erases the intersubjective meaningfulness of their content; they simply become like any other thing that belongs.

Yet, while identity beliefs are produced and consolidated as a form of social property, they are also subject to countervailing processes. For those beliefs deemed unacceptable, law may withdraw protection or even prohibit expression as has happened in some jurisdictions with the criminalisation of hate speech. Yet, as critical scholars have explored, strategies that rely on coercive and penal law can be problematic. An alternative strategy of withdrawing property protection from identity beliefs altogether also has limitations, risking a rougher social environment in which vulnerable populations are abandoned to locally dominant social norms. Therefore, without arguing that play should substitute for law (as if the two were distinct and different), can play nonetheless provide a flexible, open-ended response, which brings the political back into propertied beliefs? This may be a response that is fun, disarming and subversive, but not all the state-based play explored here falls into this category. What play-approaches do share, however, in contrast to juridical prohibition-based responses, is a readiness to transfer and repurpose beliefs (along with the property held in them). But before exploring play's presence in this legal drama any further, let me say something briefly about play.

To think play in ways that illuminate state practice, I approach it as both a quality and kind of activity involving creative, satisfying, open-ended and willing ${ }^{11}$ interactions between bodies, things and spaces. ${ }^{12}$ In many ways a familiar conceptualisation, two elements are particularly important for this account of play. First, play can be outcome-oriented even as its process may be what is fundamentally satisfying and pleasurable. Second, play has an elastic, mutable, protean quality, a surplus that exceeds what appears to be done. Play's mutability emerges in the simulation of other bodies and roles; in reusing or repurposing a terrain or object (acting as if it is other than it is usually taken to be); and in the coexistence of multiple interpretive frames or forms - that concertina-like quality of action, as it simultaneously holds and expresses different possibilities; put nicely by Bateson (1987: 185-6) when he writes: the "playful nip denotes the bite, but it does not denote what would be denoted by the bite" (see also Nachmanovitch 2009: 1). 


\section{Attaching and Securing Beliefs}

This paper focuses on state-based play; however, the legal drama over conservative Christian withdrawal reveals other kinds of play, also important for this discussion in highlighting how play can express and secure, not just unsettle, possessive beliefs. To begin with, many of the litigated disputes concerned recreational and pleasure-seeking activities as "out" lesbian and gay subjects, seeking to live out gay-positive beliefs, were turned away from guesthouse vacations, wedding venues, youth camps, and school proms. At the same time, conservative Christians claimed their right to act according to beliefs was also at stake. Conservative Christians drew on play to rationalise service-refusal in two ways. First, rejecting the servitude associated with work (Kane, 2004), Christian "conscientious objectors" asserted a mimetic sovereign defiance. While deference to God's law was often the explicit reason for rejecting same-sex couple's requests for wedding cakes, venues, or guesthouse rooms, in the process conservative Christian providers assumed (or projected) the role of an imagined ruler entitled to say "no" despite contravening secular authority. This take-up of play's imitative dimension (if not its pleasures) contrasts with a second use of play in which litigants drew explicitly on their right to artistic satisfaction as florists, wedding cake-makers, calligraphers

and photographers. ${ }^{13}$ From this perspective, the legal requirement upon them not to discriminate clashed with what Christian litigants claimed were their legitimate creative and expressive rights.

Play also emerged in more agonistic form. Leaving to one side the game-like quality of litigation itself, participants used ingenious forms of play to expose others' beliefs. With play here used for the rather unplay-like purpose of revealing others" "illegitimate" commitments, actors became play objects, toyed with as they became subjected to a "play" determined in advance (see also Kane, 2004). One such case concerned Ms Pilkington, a Christian, British-based psychotherapist, secretly recorded by a journalist who was passing as an unhappy gay man "looking to be "cured". ${ }^{14}$ An American example, in which a conservative Christian bakery was "played with" in order to unmask it, was Masterpiece Cakeshop. ${ }^{15}$ As part of the legal action brought against the cakeshop for refusing to make gay wedding or commitment ceremony cakes, Stephanie Schmalz (one of several people whose request was rejected) contacted the shop saying she was a dog breeder planning a dog wedding celebration. Her affidavit states, "I specified that for the 'dog wedding' I wanted a cake large enough to serve about 20 people, in the shape of a dog bone, and lettered with the names Roscoe and Buffy. Mr. Phillips stated no objection to filling this order."16 
What is striking in these diverse instances is how play and beliefs remain closely attached. Certainly, play takes different (including some rather unplay-like) forms; at the same time its practice is intended to secure and demonstrate subjects' relationships to their beliefs, including on occasion by unmasking them. Since liberal legal discourse depicts these identity beliefs as possessions, the question becomes not whether such beliefs "belong" (since this is largely assumed) but how their propertied contours should be drawn: where can antigay beliefs be manifested and what can they be allowed to do? Yet, the legal drama over conservative Christian withdrawal also reveals glimpses of other kinds of play, where the possessive relationship between subjects and their beliefs - Christian beliefs but not only theirs - are contested, redrawn or oriented to other ends. In tracing these other kinds of play, I explore the place of the state as it moves from facilitator, to player, to conduit, terrain and target, and address the changing relations of separation, fusion and contact enacted in the process.

\section{Role-Playing Others' Beliefs}

Liberal governments not uncommonly turn to play to promote "good relations", particularly across ethnic and cultural cleavages (Johnson and Tatam, 2009; DfE, 2014: 34). While academic assessments remain mixed $;{ }^{17}$ policy-makers suggest play can heal divisions, minimise distrust, and forge bridging capital between antagonistic or unfamiliar social groups. In Britain, the legal duty placed on public bodies to promote "good relations" is one example of a formally legislated attempt to use voluntary contact, including play, to minimise inter-cultural hostility. In other policy contexts, the need to promote better dialogue and decision-making between adversarial or distrustful participants can also give rise to play.

In their account of role-play to build consensus among governmental and community participants addressing water management and conservation in California, Innes and Booher (1999) explore how playing together over a period of time, in ways that engage people's capacity for improvisation, speculation and imagination, can help participants with competing interests and perspectives find mutually satisfactory solutions. Role-play requires people to act $a$ s if their beliefs, judgments and interests were otherwise. Thus, in the water management discussions, facilitators encouraged participants to draw on non-official, more personal roles (as cyclist rather than water board employee, for instance) to help participants get distance from their own positions and interests, and to consider solutions from analogous contexts. ${ }^{18}$ Innes and Booher's (1999) account resonates with Josh Lerner's (2014) transnational study of 
how public bodies can use games to generate more publicly engaged decision-making, such as when allocating resources. Here too, play provides a structure that helps participants to think about modes of conflict resolution which embrace others' needs and interests also.

Applied to the legal drama of conservative Christian withdrawal, we might imagine state bodies - schools, local authorities, hospitals, police forces - developing role-play activities with staff, users and publics holding competing sexual beliefs to identify strategies for handling or avoiding conservative Christian refusal. Such an approach would extend already trialled initiatives to improve working relations between "out" gay and conservative Christian staff (eg, Afridi and Warmington, 2010; Malik, 2008). However, rather than getting participants to just talk through their differences, according to a logic of tolerance and respect for different (stable) identity beliefs, role-switching, games, hypothetical outcomes, and stories of imagined times ahead might be used to temporarily loosen people's ties to their normative commitments, moral understandings and desired futures. But, aside from whether temporarily suspending or swapping beliefs through play makes any longer-term difference indeed, whether conservative Christian and liberal equality beliefs can be meaningfully bracketed, even briefly, to find win-win solutions given the intensity with which they are held $^{19}$ - using games and play to reduce conflict frames political relations in particular ways. It assumes the goal is agreement rather than sustaining dissent; treats each "side's" beliefs as equally valid (tacitly reinforcing their propertied rather than political status); and - like the policy gamification discussed by Lerner (2014) - positions state bodies apart and distinct from those they induce to play. Therefore, for the rest of this discussion, I turn to other kinds of play to have emerged in this legal drama: play that complicates and unsettles any notion of the detached, neutral, play-managing state.

\section{Nationalising Equality Beliefs}

For conservative Christians, neo/ liberal states in the global north have undertaken a massive "nationalisation" programme; converting contentious grass-roots beliefs in gay equality and gay pride into state property. This nationalisation is immediately evident in considering the very different treatment accorded to right-wing religious beliefs. While beliefs in religious equality are equally institutionalised, nation-states such as Britain treat the religious claim that gay sex is sinful as private property belonging to religious holders rather than the state and, like other forms of dangerous private property (eg, guns and fire), constrained in where it can be manifested and what it can be used to do. Facing property limitations in their own 
beliefs, conservative Christians do not read the nationalisation of gay equality as an “appropriation" but rather as reinforcing and strengthening gay people's identity property. Indeed, it is government and public agencies' protection and investment in gay equality, requiring other bodies to give life to these beliefs whether or not they actually hold them, which sparked much conservative Christian withdrawal. But in what sense does state nationalisation, and the struggles surrounding it, involve play?

We might see play's presence, or at least catch glimpses, in the inventiveness with which state bodies tackled this new agendum. ${ }^{20}$ However, I want to focus here on play's discursive take-up to slur state conduct. Both conservative Christian and gay activists used play discourse to critique state action in ways that foregrounded the political (rather than propertied) character of sexual beliefs. For conservative Christians, this involved denouncing state promotion of gay equality as irresponsible experimentation - recklessly engaged in without caring or knowing what the consequences might be. In one British case, a magistrate informed the family panel, on which he sat, that he could not assess same-sex couples seeking adoption, because "insufficient research had been undertaken in relation to whether this was desirable, and that he did not approve of the idea of children being 'guinea pigs' in the name of politically correct legislation." ${ }^{21}$ Heterodox sexualities were seemingly too risky and contentious to be subject to state innovation in support of new public beliefs. But it was not only conservative Christians who deployed imaginaries of play in order to critique the state.

In her discussion of Hegelian self-consciousness, Judith Butler (2007) gives voice to the lord's claim that the bondsman "be my body for me". Elsewhere, I have explored (and inverted) its conceptual terms to think about social movement demands that state formations take up their political projects, embodying them as if they were the state's own (Cooper, 2013). In the Hegelian story, Butler (2007: 36-38) tells, the bondsman does all the labour, yet owns nothing of what is produced, stamped by the master with his own name. In the very different story told here, "be my body" is an invocation that states stamp agendas and programs, such as gay equality, with its own name. The desire for beliefs to become public property, with the institutionalisation and empowerment presumed to follow, is an important aspect of activist state engagement (at least for some). Instead of gay equality being simply recognised as a legitimate belief for gay people to hold, the state acts as if the belief was its own. But while gay equality activists may hope their ideas or beliefs will become part of the institutional fabric, integrated with other public governance commitments, there is also 
disquiet. Writers and activists have long argued that state incorporation leads politics to be "watered down" even as (but more likely because) state bodies mark such politics with their own signature (eg, Ahmed 2012; Carabine and Monro, 2004: 319). In part, this dilution is associated with the contradictory character of state formations engaged in supporting competing projects, giving voice to divergent rationalities and logics, and embodying contrasting agendas. But it also comes from the way beliefs, unlike many forms of property, appear as non-fungible. Transferred to and taken up by new (institutional) bodies - in Rancière's (2004) terms moving from politics to police - beliefs change.

Running through sexual activists' engagement with public authorities, then, is a longstanding unease that states are playing and playing inappropriately. For play is read as meaning public bodies are not properly committed to gay equality, contributing a signature that is dramaturgical rather than productive, enacting a performance not intended to have performative effects (also Ahmed, 2012). Public bodies may refer to their objectives and goals but these are read critically as simply part of the play - lacking life beyond the "magic circle" in which contentious, not really intended to be realised, public projects languish (see also Lind and Keating 2013). Yet, while gay activists use play's terms and imagery to discount the reality of state commitment, they simultaneously maintain a complex relationship to property in gay equality beliefs. On the one hand, as guardians, they sustain a collective, steward-like property, demanding states make public ownership of gay equality beliefs meaningful. At the same time, scepticism about the state feeds an understanding of such equality beliefs as political claims to be fought over rather than beliefs to secure, protect, and recognise simply because they belong to gay subjects. Treating gay equality as a political claim also underpins a further relationship between activists and state bodies. While activists may ask states to "be my body for me", sometimes the relationship is reversed so that activists come to embody or ventriloquise state beliefs. And sometimes they may do so in ways that are not simply a transmission but also a translation: re-making the public property held in such beliefs. I want to consider this wily kind of play in ANT terms as "kick-back" where those ostensibly enrolled in supporting state property reframe it in ways that (tacitly) challenge official discourse.

\section{Playing as if Activist Beliefs were State Beliefs}

My example comes from a media story about a British trainer running a homophobic awareness session for teachers. ${ }^{22}$ According to one teacher who attended, at some point during 
the day the trainer remarked: 'What makes you all think that to be heterosexual is natural?'23 At this point, the teacher, along with several others, walked out. ${ }^{24}$ The teacher was subsequently suspended, ${ }^{25}$ in part for comments later relayed to the organisers regarding God's wrath towards homosexuals, comments which vandalised, in a sense, state-held property in liberal sexuality beliefs. However, we might also read the trainer's quoted remarks as an instance in which a social movement activist refused to play exactly as she was supposed to, stepping outside the liberal terms of anti-homophobic training even as the mantle of state-mandated action authorised her question. Exposing the social character of heterosexuality challenged conservative religious beliefs along with liberal state ones. It also expressed a belief outside the logic of possessive belonging. Questioning heterosexuality's naturalness was not intended as a claim to, or an enactment of, property (that the belief deserved to be institutionally recognised, protected and empowered as something belonging to the trainer). Rather, what was asserted was the belief's political character, even as the context and performance - challenging heteronormativity in an officially designated teacher training session - re-presented the belief as public property; in other word as a belief proper to the official training she had been employed to provide.

We can read the trainer's intervention in terms other than play. But what play illuminates, in incidents such as this, is the satisfaction that can come from challenging ingrained beliefs; the concertina-like relationship to state authority (acting as if speaking on behalf of the state while knowing one is not); and the game-type moves that follow. While far from contained within play's "magic circle", dramas like this develop their own tempo, rhythms and spaces, generating moves that appear increasingly un-playlike, particularly as disciplinary action and sanctions get invoked. Provocations, such as this trainer's, may appear very modest, but they can precipitate a series of events that end with dismissal and litigation. Yet, as a way of destabilising public and private propertied beliefs, the problem with kickback lies in the fragility of the initial challenge. As one game move leads to another and institutional processes take over, the playful force of the original provocation: 'What makes you all think that to be heterosexual is natural?' gets quickly lost.

So far, I have discussed the transactional movement of beliefs through play where others' beliefs are held or imitated as if they belonged (temporarily or permanently) to the holder/ imitator or, in the case of the trainer just discussed, as if the player's beliefs actually belonged to the state. In my final discussion, I want to consider a different scenario in which gay groups used nationalised beliefs in gay equality to play downwind with resistant local 
authorities. The episode, a Canadian legal drama from the late 1990s, concerned city mayors who refused to issue gay pride proclamations in contexts where proclamations for other causes were routinely given. ${ }^{26}$ Interestingly, when litigated, the courts repeatedly found in favour of gay claimants challenging the proclamation denials. Mayors could not refuse to "endorse" homosexuality; nor could they deny it "pride" given the particular history of its attachment. ${ }^{27}$ In this way, courts treated gay pride as both valuable and vulnerable.

At one level, these mayoral proclamation cases can be read as invoking an entitlement to celebratory play, treating it as a communal rather than merely individual property that a mayoral proclamation adds value to. At another level, the cases reveal grass-roots attempts to citify gay pride as a publicly held property, whose endorsement not only affirmed gay equality as a legitimate belief for gays, collectively and individually, to hold but as something belonging to the city also. But what I want to explore, in this legal drama, is the way provincial (and so formally superordinate) gay rights norms were deployed to play with the local state. The alignment between provincial and activist beliefs in gay equality was not here about activists' stewardship - maintaining custodianship of beliefs in conditions where public bodies appear to be merely playing - but rather using the pincer-like character of coownership to make contact with city councils. We can read this contact, with its improvised tactics, energies, rhythms, and "as if" qualities, as playful. I want to think about it as "freerunning" the state.

\section{Free-Running States}

In its more familiar physical form, free-running (otherwise known as parkour) constitutes a highly skilled, recreational activity of running, tumbling, scaling and mounting predominantly urban, human-engineered landscapes (Saville, 2008); a way of re-experiencing alienating physical terrain as stimulating and challenging rather than grim and depressing (Atkinson, 2009; also O'Grady, 2012). Here, I consider free-running the neo/ liberal state in conditions where superordinate institutional recognition made toeholds in subordinate state apparatuses both possible and desirable.

As a playful way of doing politics and a political way of doing play, state free-running shares something in common with the "rhetorical art of jujitsu", in which, according to Christine Harold (2007: 191), "existing cultural forms" are "playfully and provocatively fold[ed]... in on themselves", in an effort to redirect these forms "toward new ends". However, the kind of jujitsu Harold (2007) describes tends to involve wittily redirecting or 
reversing corporate and product messages to consumers. By contrast, the free-running I discuss uses superordinate state norms and authority to re-tether and redeploy a "delinquent" state part. State free-running also parallels the "city hacking" described by Michiel de Lange; a process in which citizens envision themselves as agents of social change, able to and intent on reshaping their urban environment. ${ }^{28}$ Like city hacking, free-running involves the pleasure of undertaking a challenge as well as the curiosity piqued by tinkering with things to discover how they work. However, free-running the state is less intent on reconfiguring the political landscape than playfully re-purposing it. This doesn't mean free-running accepts the neoliberal institutional landscape. However, its focus is on the political opportunities and resources (symbolic and material) that neo/ liberal state bodies (intentionally or otherwise) make available. ${ }^{29}$

Free-running reveals how institutionally recognised and accepted beliefs generate traction. In the pride proclamation cases, free-runners take up identity beliefs that have become superior state property, yet still remain attached to them, in part because the beliefs are about them and what they are due. ${ }^{30}$ Anarchists and postcolonial scholars are typically critical of the desire for recognition from an oppressive state formation (eg, see Coulthard, 2014). But from a different left perspective, recognition becomes a register or means of action rather than its goal; one that enables activists to make contact (which can be for many different purposes) with public bodies. In his study, Atkinson (2009: 190) cites interviewee descriptions of free-running as being like "flowing water", which "effortlessly pass[es] across, under, over, or around any environmental obstacle it encounters". Community activists in the mayoral proclamation cases likewise cross state bodies swiftly and surely, searching for crevices and protuberances that might make a productive grip possible. ${ }^{31}$ Engaged in an improvised form of political dance (also Saville, 2008: 899), they go from mayoral office to sympathetic politicians, to bureaucrats, city council committees, and eventually to the courts, pursuing a proclamation. ${ }^{32}$

In free-running, it is suggested, bodies and landscapes blend. According to Atkinson (2009: 170), the "lines separating roads, buildings, cultures, selves, and bodies disappear[]". But when it comes to state free-running, this fusion is not always welcomed. An American case, which demonstrates this, involves not the superordinate state of the pride proclamation cases but an attempt by gay activists to mobilise city equality commitments and so remove a building subsidy from the local Boy Scouts because of the latter's exclusionary policy towards gay men, which violated city non-discrimination laws. ${ }^{33}$ One aspect of the case concerned whether a gay lobby group, the "working group", had exerted improper influence 
on the, then, city solicitor. The evidence was a series of email exchanges set out in the judgment. One email from the group reminded the city solicitor not to do "a disservice to the LGBT community of which you are a part" (italics added). ${ }^{34}$ Repeatedly, emails asked for copies of draft letters from the City to the Boy Scouts to be circulated to group members; identified members as advocating going "public about the City's... secret agreement"; and imperiously remarked: "your recent communication with the Scouts may indicate a willingness on your part to move in the right direction. On the other hand, a meeting in the near future really does mean the near future" (italics added). ${ }^{35}$

Emails from the working group suggest a mimetic enactment of governmental authority and, as such, demonstrate how co-ownership of gay equality can be deployed, not always in progressive or apparently appropriate ways, to assert a governmental fusion. But such fusion can also be resisted. The Cradle of Liberty Council judgment also includes the emailed replies of the city solicitor, kicking back against the working group's assertion of governmental authority. ${ }^{36}$ While the city solicitor's response was criticised by the plaintiffs, read against the working group's emails, his brief replies suggest a polite refusal to be dictated to as well as a reminder of his legal role in contrast to their position as community members. More generally, we can read his response as refusing free-running's attempt to meld political bodies through the deployed device of ostensibly shared identity beliefs.

The discomfort expressed in the Cradle of Liberty Council emails raises an important issue for the pride proclamation cases. In state free-running, activist attempts to tumble and traverse state machinery at speed - crossing and invoking procedures, personnel, powers and places - can lead to exposure, upset and humiliation as several proclamation cases describe. In Hudler, the court commented on the "great deal of negative ...even hostile comment about the club [that sought the proclamation] ....in radio phone-in shows; in letters to the editor... in telephone calls and letters [to the club]... and in conversations on the street and in the workplace." ${ }^{37}$ Can attempts to get a proclamation, then, be usefully considered play given the risks of getting hurt? This is a difficult issue. I do not want to trivialise the stress and vulnerability caused by pride proclamation challenges, nor the many non-play ways in which participants understood their involvement and the effects of refusal. In Hudler, lesbian and gay community members spoke about "feeling personally hurt and diminished"; the negative effects of refusal on other gay service users; and the chilling effect on other public bodies". 38 However, my account does not treat mayoral refusals as play, nor equate state free-running with frivolity but rather with willing, creative moves that skilfully traverse the boundary between safety and harm, with its mingling of anger, pain and pleasure (see also Saville 
2008: 892-3). More generally, what state free-running usefully emphasises is the edgy pleasure and emotional intensity that can come from making contact with a body that wants to resist but will eventually prove unable to. This is a body, whose belief in homosexuality's undesirability has become precarious, absent the institutional protection necessary for it to act governmentally. Superordinate state law has recalibrated property in beliefs, and mayoral attempts to treat homosexuality as worthless have become officially de-authorised. While local cities may continue to kick-back, state free-running (and the litigation it enrolled) imposed a new propertied settlement, such that cities became obliged to express gay equality beliefs as if they held them.

\section{Conclusion}

The notion that personhood has become increasingly subject to a property logic is far from new. Many scholars have drawn on Locke, Hegel and other foundational property thinkers to explore the relationship between ownership, things and the self. However, little of this work foregrounds the contemporary propertisation of identity beliefs as these become legally defined, recognised, protected and enabled as things that "belong" and, as such, worthy of respect. Anti-discrimination and human rights law provisions have been important contributors to this process, formally equalising the property that recognised identities and beliefs can bear - a redistribution that remains far from uncontentious as the legal drama over liberal gay equality norms and conservative Christian withdrawal highlights. However, while this legal drama has focused on the rights and legitimate expectations of different parties, the political currents swirling around it also reveal a different mode of engagement, namely of play.

With its mischievous, imitative, plastic modes of action, play can seem to rework the tight attachments between subjects and their beliefs through a series of transactional moves. The first I explored involved public bodies using role-play and consensus-building to encourage people to temporarily suspend their attachments to particular beliefs (or interests) to find new creative resolutions to conflicts. In the second, social movements passed their beliefs to states who represented them mimetically in ways that also changed the beliefs in question. In conditions where activists felt obliged to remain attentive to how states took up their beliefs, attuned to the "as if" game-like quality that often seemed to accompany state claims that equality beliefs belonged to them, other forms of play also emerged. One involved kick-back, where those enrolled in equality programs refused to just be conduits of state- 
assumed beliefs, and instead used the institutional spaces and opportunities made available to express grass-roots ideas as if they were state ones. Here, rather than asking the state to "be my body for me", activists took up the position of the state's body, simulating state authority while expressing non-state beliefs. Finally, in state free-running, activists traversed an institutional landscape of state machinery, using skill, persistence and, in my example, the resources of superordinate state recognition to make contact with dissident city councils, where thanks to subsequent court backing, activists compelled municipal bodies to speak and act identity beliefs they did not want to hold, such as gay pride, as if they held them.

Teasing out these complex relations highlights the circulatory character of this form of play. Beliefs move between players, and get stuck upon play's objects, as groups, individuals, and state bodies act as if the beliefs they now express are theirs, or as if their beliefs now belong to another. But while this may seem like an elaborate card game, its value is far from ludic. Play is often read in polarised ways - romanticised by advocates, dismissed by critics. The account offered here, by contrast, traces a middle path. While my starting point was the potential for play to unsettle possessive beliefs, exploring this potential led me to address the ways play may reinforce such beliefs or draw on shared (and propertied) beliefs to make contact with institutional bodies possible. This equivocation is unsurprising since we are talking about play which, with its multiple frames of meaning and action, necessarily refuses any easy instrumentality or use. But while this may suggest play is no simple solution to the problem of possessive beliefs, it also suggests that the dismissal of state-based play - either alongside the dismissal of the state or in order to retrieve the state as a weighty formation - is equally faulty. ${ }^{39}$

This article has explored some ways state-based play shapes and frames political relations. Doing so prompts, in turn, more normative questions about the value of play involving states - not only play that satirically critiques state action (the subject of much academic discussion), but play that state bodies actively engage inalso.. State play can be cruel and harmful to those who become its objects; it may distract and trivialise; reinforce asymmetries of need; and seal off important political issues from the heartland of governance activities. For state play to support a progressive transformative politics, far more democracy, freedom, equality and social justice are necessary. But with these caveats in mind, recognising that not all state-based play is state-organised play, and recognising too that playing with states may over time change what states are (like), play poses an interesting and challenging register for thinking about governing - how it happens but, more importantly, how it could happen. With its creativity, openness and pleasures (melancholy pleasures as 
well as exciting, risky pleasures), play, I think, deserves far more attention in what it can offer for doing - which may inevitably be a prefigurative doing of - institutional life.

\section{References}

Adkins, Lisa (2005) The new economy, property and personhood. Theory, Culture \& Society 22(1): 111-130.

Afridi, Asif and Joy Warmington (2010) Managing Competing Equality Claims. London: Equality and Diversity Forum.

Ahmed, Sara (2012) On Being Included: Racism and Diversity in Institutional Life. Durham: Duke University Press.

Andersson, Johan, Robert M. Vanderbeck, Gill Valentine, Kevin Ward, and Joanna Sadgrove (2011) "New York encounters: Religion, sexuality, and the city." Environment and PlanningPart A 43(3): 618-633.

Aretxaga, Begona (2000) "Playing terrorist: Ghastly plots and the ghostly state." Journal of Spanish Cultural Studies 1(1): 43-58.

Atkinson, Michael (2009) "Parkour, anarcho-environmentalism, and poiesis." Journal of Sport \& Social Issues on-line doi:10.1177/0193723509332582.

Bateson, Gregory (1987) Steps to an Ecology of Mind. Northville, NJ: Jason Aronson.

Butler, Judith (1997) The Psychic Life of Power: Theories in Subjection. Stanford: Stanford University Press.

Butler, Judith and Athena Athanasiou (2013) Dispossession: The Performative in the Political. Cambridge: Polity.

Caillois, Roger (1961) Man, Play, and Games. Translated by Meyer Barash. New York: Free Press. 
Carabine, Jean, and Surya Monro (2004) "Lesbian and gay politics and participation in New Labour's Britain." Social Politics: International Studies in Gender, State \& Society 11(2): 312-327.

Cooper, Davina (1994) Sexing the City: Lesbian and Gay Politics within the Activist State. London: Rivers Oram.

----- (2013) "Public bodies: Conceptualising active citizenship and the embodied state." In Roseneil S (ed) Beyond Citizenship?: Feminism and the Transformation of Belonging. London: Palgrave Macmillan.

----- (2015) "Bringing the state up conceptually: Forging a body politics through anti-gay Christian refusal." Feminist Theory 16(1): 87-107.

----- (2016) "Retrieving the state for radical politics - A conceptual and playful challenge." Journal of Social Policy Studies 14(3): 409-422.

----- (2017) “Prefiguring the state." Antipode 49(2): 335-356.

Cooper, Davina and Didi Herman (2013) "Up against the property logic of equality law: Conservative Christian accommodation claims and gay rights." Feminist Legal Studies 21(1): $1-20$.

Coulthard, Glen Sean (2014) Red Skin, White Masks: Rejecting the Colonial Politics of Recognition. Minneapolis: University of Minnesota Press.

Department for Education (2014) The Equality Act 2010 and Schools. London: Government Publications.

Edwards, Jason (2013) "Play and democracy: Huizinga and the limits of agonism." Political Theory 41(1): 90-115. 
Ferguson, James (2002) "Of Mimicry and membership: Africans and the new world society." Cultural Anthropology 17(4): 551-569.

Goldberg-Hiller, Jonathan and Neal Milner (2003) "Rights as excess: Understanding the politics of special rights." Law \& Social Inquiry 28(4): 1075-1118.

Grabham, Emily (2009) "'Flagging' the skin: Corporeal nationalism and the properties of belonging." Body \& Society 15(1): 63-82.

Harold, Christine (2004) "Pranking rhetoric: "Culture jamming” as media activism." Critical Studies in Media Communication 21(3): 189-211.

Harris, Cheryl (1993) "Whiteness as property." Harvard Law Review 106(8): 1707-1791.

Herman, Didi (1997) The Antigay Agenda: Orthodox Vision and the Christian Right.

Chicago: University of Chicago Press.

Huizinga, Johun (1970) Homo Ludens: A Study of the Play Element in Culture. London: Temple Smith.

Hunt, Stephen (2011) "A turn to the rights: UK conservative Christian lobby groups and the 'gay debate'." Religion \& Human Rights 6(3): 291-313.

Innes, Judith and David Booher (1999) "Consensus building as role playing and bricolage: Toward a theory of collaborative planning." Journal of the American Planning Association 65(1): 9-26.

Johnson, Nick and John Tatam (2009) Good Relations: A Conceptual Analysis. London: Institute of Community Cohesion.

Kane, Pat (2005) The Play Ethic: A Manifesto for a Different Way of Living. London: Pan Macmillan. 
Keenan, Sarah (2010) "Subversive property: Reshaping malleable spaces of belonging." Social \& Legal Studies 19(4): 423-439.

Lerner, Josh (2014) Making Democracy Fun: How Game Design can Empower Citizens and Transform Politics. Boston: MIT Press.

Lind, Amy, and Christine Keating (2013) "Navigating the left turn: Sexual justice and the citizen revolution in Ecuador." International Feminist Journal of Politics 15(4): 515-533.

Macpherson, C.B. (1962) The Political Philosophy of Possessive Individualism: Hobbes to Locke. Oxford: Clarendon.

Malik, Maleiha (2008) From Conflict to Cohesion: Competing Interests in Equality Law and Policy. London: Equality and Diversity Forum.

----- (2011) "Religious freedom, free speech and equality: Conflict or cohesion?" Res Publica 17(1): 21-40.

McConnell, Fiona, Moreau Terri, and Jason Dittmer (2012) "Mimicking state diplomacy: The legitimizing strategies of unofficial diplomacies." Geoforum 43(4): 804-814.

McNay, Lois (2009) "Self as enterprise: Dilemmas of control and resistance in Foucault's the Birth of Biopolitics.” Theory, Culture and Society 26(6): 55-77

Nachmanovitch, Stephen (2009) "This is play." New Literary History 40(1): 1-24.

Nedelsky, Jennifer (1990) "Law, boundaries, and the bounded self." Representations 30: 162189.

O'Grady, Alice (2012) "Tracing the city-parkour training, play and the practice of collaborative learning." Theatre, Dance and Performance Training 3(2): 145-162.

Pynes, Joan (2016) “The Boy Scouts of America: Slowly changing.” Journal of Homosexuality 63(1): $52-71$. 
Radin, Margaret Jane (1993) Reinterpreting Property. Chicago: University of Chicago Press. Rai, Shirin (2015) "Political performance: A framework for analysing democratic politics" Political Studies 63(5): 1179-1197.

Rancière, Jacques (2004) Disagreement: Politics and Philosophy. Minneapolis: University of Minnesota Press.

Saville, Stephen John (2008) "Playing with fear: Parkour and the mobility of emotion." Social \& Cultural Geography 9(8): 891-914.

Shepard, Benjamin (2011) Queer Political Performance and Protest. New York: Routledge.

Spracklen, Karl, Jonathan Long, and Kevin Hylton (2015) "Leisure opportunities and new migrant communities: Challenging the contribution of sport." Leisure Studies 34(1): 114-129.

Stychin, Carl (2009) "Faith in the future: Sexuality, religion and the public sphere." Oxford Journal of Legal Studies 29(4): 729-755.

Sutton-Smith, Brian (2009) The Ambiguity of Play. Cambridge: Harvard University Press.

Valentine, Gill (2008) "Living with difference: Reflections on geographies of encounter." Progress in Human Geography 32(3): 323-327.

Valentine, Gill and Louise Waite (2012) "Negotiating difference through everyday encounters: The case of sexual orientation and religion and belief." Antipode 44(2): 474-492.

Vickers, Lucy (2010) "Religious discrimination in the workplace: an emerging hierarchy?" Ecclesiastical Law Journal 12(3): 280-303.

Vincent, Carol, Sarah Neal, and Humera Iqbal (2017) "Encounters with diversity: Children's friendships and parental responses." Urban Studies 54(8): 1974-1989. 
Young, Iris Marion (1997) "Asymmetrical reciprocity: On moral respect, wonder, and enlarged thought." Constellations 3(3): 340-363. 


\section{Notes}

I am grateful for feedback and comments from Margaret Davies, Didi Herman, Bonnie Honig, Sarah Keenan, John Ackerman and TCS referees, as well as participants at presentations and discussion at Birkbeck, Brunel, Brown, Kent and Berkeley.

\section{Biographical Note}

Davina Cooper is a Research Professor at the Dickson Poon School of Law, King's College London. Current research involves reimagining the state for a progressive transformative politics; and an ESRC-funded critical law reform project on general gender assignment. Her books include Everyday Utopias (Duke UP), Challenging Diversity (CUP), and Governing out of Order (Rivers Oram).

\footnotetext{
${ }^{1}$ In relation to states outside the neo/ liberal north, a more established and extensive literature on play, mimesis and fantasy exists, recognising these processes may also have little to do with frivolity and pleasure, eg Aretxaga (2000); Ferguson (2002); McConnell et al (2012).

${ }^{2}$ For discussion of recent history of conservative Christian opposition to gay rights, see Herman (1997), Hunt (2011), Goldberg and Miller (2003).

${ }^{3}$ Johns v. Derby City Council [2011] EWHC 375.

${ }^{4}$ See for instance, Trinity Western University v. The Law Society of Upper Canada, 2016 ONCA 518.

${ }^{5}$ These questions are part of a larger research project on reimagining what it could mean to be a state in ways that might support a progressive transformative politics, see Cooper $(2015,2016,2017)$.

${ }^{6}$ For accounts, drawing on other literatures, of how the relationship between persons and property in the self is being restructured within contemporary social and economic life, see Adkins (2005) and McNay (2009).

${ }^{7}$ See for instance the exchange between Lord Carey and LJ Laws in McFarlane v Relate Avon [2010] EWCA 880.

${ }^{8}$ See Neuberger's rejection of the notion that heterosexual marriage constituted a "core" aspect of Christianity, Ladele v LB Islington [2009] EWCA 1357, para 52.

${ }^{9}$ See Vickers (2010: 295), arguing courts should not determine whether particular beliefs are core or peripheral to a religion.

${ }^{10}$ See, for instance, British cases of Smith v. Trafford Housing Trust [2012] EWHC 3221; Haye v London Borough of Lewisham (2010) ET 2301852/2009; and Mbuyi v. Newpark Childcare [2015] ET 3300656/2014.

${ }^{11}$ This doesn't mean all participants engage voluntarily; to the extent they become objects of play, their active consent or intentional participation may seem doubtful. Necessity also undermines voluntary participation; where people are state clients, for instance, the asymmetry of the relation, and the need - often urgent and desperate - for state resources puts the capacity of state officials and applicants to play together as horizontal subjects firmly in doubt.

${ }^{12}$ In addition to citations elsewhere in the text, core academic sources include Caillois (1961), Huizinga (1970) and Sutton-Smith (2001).

${ }^{13}$ E.g., see Brush and Nib v. City of Phoenix, Verified Complaint, CV2016 - 052251; 12 May 2016; available from Alliance defending Freedom website: https://adflegal.blob.core.windows.net/web-contentdev/docs/default-source/documents/case-documents/brush-nib-studio-v.-city-of-phoenix/brush-amp-nib-studioV-city-of-phoenix---complaint.pdf?sfvrsn=8 (accessed 29 October 2017).

${ }^{14} \mathrm{http} / / / \mathrm{www}$. theguardian.com/world/2011/may/27/gay-conversion-therapy-patrick-strudwick

${ }^{15}$ Craig and Mullins v. Masterpiece Cakeshop, 2015COA115 (Colorado Court of Appeal).

${ }^{16}$ See Affidavit, para 12, http://static.aclu-co.org/wpcontent/uploads/files/Affidavit\%20of\%20Stephanie\%20Schmalz.pdf (accessed 29 October 2017).

${ }^{17}$ For interesting research, see Andersson et al., (2011); Spracken et al., (2015); Valentine (2008); Valentine and Waite (2012); and Vincent et al., (2017).

${ }^{18}$ Innes and Booher (1999) also suggest play elements, such as drama, emotion, story-telling and humour, can help manage tensions and power inequalities.

${ }^{19}$ For a critical account of whether we can step into another's "shoes", see Young (1997).

${ }^{20}$ I have explored this in detail in Cooper (1994).

${ }^{21}$ McClintock v. DCA, [2007] UKEAT 0223_07_3110, para 20 (Elias J.).

${ }^{22}$ Christian teacher suspended for complaining over gay rights presentation, Pink News 27 April 2009.
} 
${ }^{23} \mathrm{http} / / \mathrm{www} . c h r i s t i a n t o d a y . c o m / a r t i c l e / c h r i s t i a n . t e a c h e r . s u s p e n d e d . f o r . o p p o s i n g . p r o g a y . t r a i n i n g / 23180 . \mathrm{htm}$ (accessed 29 October 2017).

${ }^{24}$ Ibid.

${ }^{25}$ Elizabeth Pears, "Tottenham teacher suspended after gay rights row", Tottenham and Wood Green Independent, 29 April 2009; http://www.thetottenhamindependent.co.uk/news/4329788.display/ (accessed 29 October 2017)

${ }^{26}$ In one case where the New Brunswick Human Rights Commission ordered a mayor to make a proclamation, he did so at city council only after turning off his microphone, see "Fredericton mayor infuriates city gays", CBC 10 February 1999.

${ }^{27}$ Okanagan Rainbow Coalition v. City of Kelowna, 2000 BCHRT 21.

${ }^{28}$ http://thehackablecity.nl/author/michiel-de-lange/ (accessed 29 October 2017).

${ }^{29}$ This raises important issues, too complex to do justice here, about free-running in more authoritarian state contexts since free-running depends on being able to re-utilise the (political-institutional) landscape alongside a desire or readiness to make institutional contact.

${ }^{30}$ Thus, we might compare gay rights with socio-sexual projects or philias where contact with state bodies takes a repressive and punitive rather than enabling form as well as those philias, the erotic desire to touch velvet garments, for instance, unlikely to support state contact altogether.

${ }^{31}$ In free-running, infrastructural bodies are often stationary and free-runners are in movement; but the sport can involve mobile urban spaces. This same range exists in free-running states, as the movement of activists meets the relatively stationary as well as mobile parts of public bodies, with their procedures, policies, responsibilities, powers, and staff.

${ }^{32}$ E.g., see Hudler v. City of London [1997] O.H.R.B.I.D. No. 23.

${ }^{33}$ Cradle of Liberty Council v. City of Philadelphia, 851 F.Supp.2d 936 (2012).

${ }^{34}$ Ibid, 950

35 Ibid, 951.

${ }^{36} \mathrm{Ibid}$.

${ }^{37}$ Hudler v. City of London [1997] O.H.R.B.I.D. No. 23, para 41.

${ }^{38} \mathrm{Ibid}$, para 42.

${ }^{39}$ I discuss these lines of thought regarding the state further in Cooper $(2016,2017)$. 